\title{
Climate Responsive Strategy Matrix for Designing Buildings in India
}

\author{
N. Thakur*, D. Parashar*, C. Chidambaram* and M. Dharwal**† \\ *School of Architecture and Planning, Sharda University, Greater Noida, India \\ **School of Business Studies, Sharda University, Greater Noida, India \\ $†$ Corresponding author: M. Dharwal; mriduldharwal22@gmail.com
}

Nat. Env. \& Poll. Tech.

Website: www.neptjournal.com

Received: 05-09-2020

Revised: $09-11-2020$

Accepted: $12-11-2020$

\section{Key Words:}

Climate responsive strategies

Thermal comfort

Green buildings

Climatic zones

\begin{abstract}
The starting point for a good design of any building project is the analysis of the macroclimate and microclimate of the building site that encompasses an understanding of temperature, radiation, wind, precipitation, topography, vegetation, ground cover, etc., which together describe the site climate. Although urban context somewhat unifies, climate and topography prevalent in India are varied and diverse. Most part of the country is hot, while some regions are dry throughout the year, some are humid and some others are composite. The building design features, therefore, need to vary with the diversity to provide comfortable environments naturally. The context and the requirements for thermal comfort provide the basis for building siting, selection of building form and envelope, fenestration design, choice of materials, and other aspects. The paper proposes and discusses the various climate-responsive design strategies that are best adapted for the different climatic zones of India and presents such design interventions and features as a comparative matrix. Such a comparative presentation is novel, convenient, easy to comprehend, and provides a useful toolkit for building designers. The climateresponsive interventions in building design proposed in this study have the potential to enhance built environments naturally, thereby mitigating the adverse environmental impact. The proposed strategies are also validated through a sample field survey responded by building professionals from various climatic zones of the country.
\end{abstract}

\section{INTRODUCTION}

The built environment has evolved continuously over a period of time and ages along with the rapid developments as well as technological advancements. Traditionally, local contextual features dominated Architecture by considering aspects of climate, availability of local materials, and local techniques. In recent times, architecture has evolved leaving its local and vernacular forms and adopted global unifying characters, which depend largely on using active means of making buildings thermally comfortable that has resulted in large consumption of energy by the buildings. With increasing energy consumptions and concerns of severe environmental impacts like climate change, depleting ozone layer, and issues of global warming have been on the rise (Jung et al. 2013). The energy efficiency of buildings is the norm prescribed in most environmental policies at the International as well as the National levels (Perez-Lombard et al. 2008).

The building design is the major aspect that provides energy efficiency and enables thermally comfortable living environments. It is imperative that the design processes become appropriate and aid in achieving thermal comfort thereby reducing energy demand. Sustainable development requires reducing energy consumption and minimizing the impact of the environment on built structures (Choi et al.
2016). The overall energy consumption by buildings is $40 \%$ which is responsible for high carbon emissions. Efforts in recent years have been to reduce $\mathrm{CO}_{2}$ emissions through the conservation of energy (Harish \& Kumar 2016). The building energy consumption is also a response to the climatic zone. Any two climatic zones cannot be considered and addressed as one (Yilmaz 2007). Designing energy-efficient buildings in different climatic conditions would need the study and analysis of the various climatic zones and their impacts. This also includes the study of the use of materials and components that are suitable to the climate and also crucial for sustainable development.

Each climatic zone requires different design techniques which need to be addressed appropriately by understanding climate variables including temperature, radiation, rainfall, wind speed and direction, and humidity, to design sustainable buildings. Designing for the climate is crucial for design sustainability, which if addressed correctly can save massive amounts of heating and cooling energy whilst sustaining occupants' thermal comfort (Albatayneh et al. 2018). Several methods and software on energy simulations of buildings have been developed but still lack a high interaction capability between the real energy data and theoretical data (Venkataraman \& Kannan 2013). There is a need to co-relate 
the outputs of the models based on the study of the indicators with the strategies adopted and practiced in the various climatic zones. In this perspective, it is imperative that the design processes become appropriate and aid in addressing the issues. It has been noted that the initial phases of design are crucial in setting out the building performance in terms of choice of resources, the energy consumption, and life cycle costs of the buildings (Kovacic \& Zoller 2015).

This study attempts to identify and develop strategies that are responsive to the different climatic zones within India. It identifies the strategies based on the design parameters/ groups that form a part of the preliminary design of any building. The aim is to develop a strategy matrix that could be a ready reckoner for practitioners in the fields of architecture, design, and allied disciplines. The study has been conducted during 2019-2020 in India.

\section{MATERIALS AND METHODS}

The study firstly adopts the methodology cited by Krishnan et al. (2014) in the "Climate Responsive Architecture, A Design Handbook for Energy Efficient Buildings" for identifying the parameters to be addressed to design a climate-responsive building. Further, the conventional approaches of architects and designers while designing buildings are evaluated objectively. These are co-related with the parameters cited above to give "groups" that are synonymous with the building design process. Relevant sources in the area of sustainability and green buildings in India like TERI (Tata Energy and Research Institute) GRIHA (Green Rating for Integrated Habitat Assessment) have been analyzed for inputs against the parameters. The Climate consultant software that helps in climate analysis has been used for assessing thermal comfort through the study of Psychrometric charts, and the indicators of climate that are to be addressed in terms of the design process related to the parameter groups. A climate strategy matrix is then developed addressing the parameters and the five climatic zones within India. The matrix has been then validated through a survey from professionals in the area for further contextual inputs. The final matrix is collated and presented as a ready reference appropriate to all climatic zones in India.

The scope of the study is to develop a matrix on a given set of parameters. As the building design is a complex process and driven largely by the understanding of local contexts and inputs therein, it does not directly measure the indicators and relies on the existing database available as inputs for making the inferences.

\section{Climatic Zones in India}

The diversity of India is also reflected in its climate due to the various geographical features around and within its boundaries. India lies in the tropical climatic zone and is primarily dominated by high temperatures. Within its boundaries, the entire country from the North to the South and from East to West is divided into 5 climatic zones as indicated in Fig. 1. The climatic zones in India are as below:

1. Cold Climate

2. Composite Climate

3. Hot and Dry

4. Warm and Humid

\section{Temperate Climate}

The high altitudes in the Northern part of the country are demarcated as the cold zone. The great Himalayan mountain range further divides it into two zones, the lower part of the Himalayas being cold and cloudy whereas the upper part is cold and dry. The western part which lies within the purview of the great Indian Thar desert, flanked by the Aravalli range is the hot and dry zone that receives minimal rainfall. The coastal strip along the west, south and east due to its vicinity to the Arabian sea, Indian Ocean, and the Bay of Bengal respectively are classified as the warm and humid zone. The central part of the country which is prominently land-locked within these three zones experiences composite climatic conditions. The country also has moderate climatic conditions known as the temperate zone which is experienced by only two cities of India -Pune, and Bengaluru.

\section{Climate Responsive Building Design}

The building design is complex and involves the building to be built around complex parameters of the natural environment. Prior to the advent of air conditioning and mechanical ventilation systems, sun and wind were the only determinant forces for the design of the building. Therefore, the building typologies varied from place to place which gave a distinct vernacular character to the built form which responded well to the climatic conditions without relying on any active mechanical means to keep the occupants thermally comfortable. Similarly, as the buildings were designed keeping in mind the impact of the climate on them, so was the use of local materials or native technologies, that did not have an adverse impact on the local micro climate of the place at large. The buildings relied on providing thermally comfortable living conditions to the occupants through climate-responsive building design. Although the primary objective of the built spaces is still the same in current times i.e. to provide healthy and comfortable living conditions to the occupants, since the advent of the new technologies and gradual developments in the building industry, the building designers have drifted their ways to provide habitats with more reliance on the mechanical means rather than passive means. 


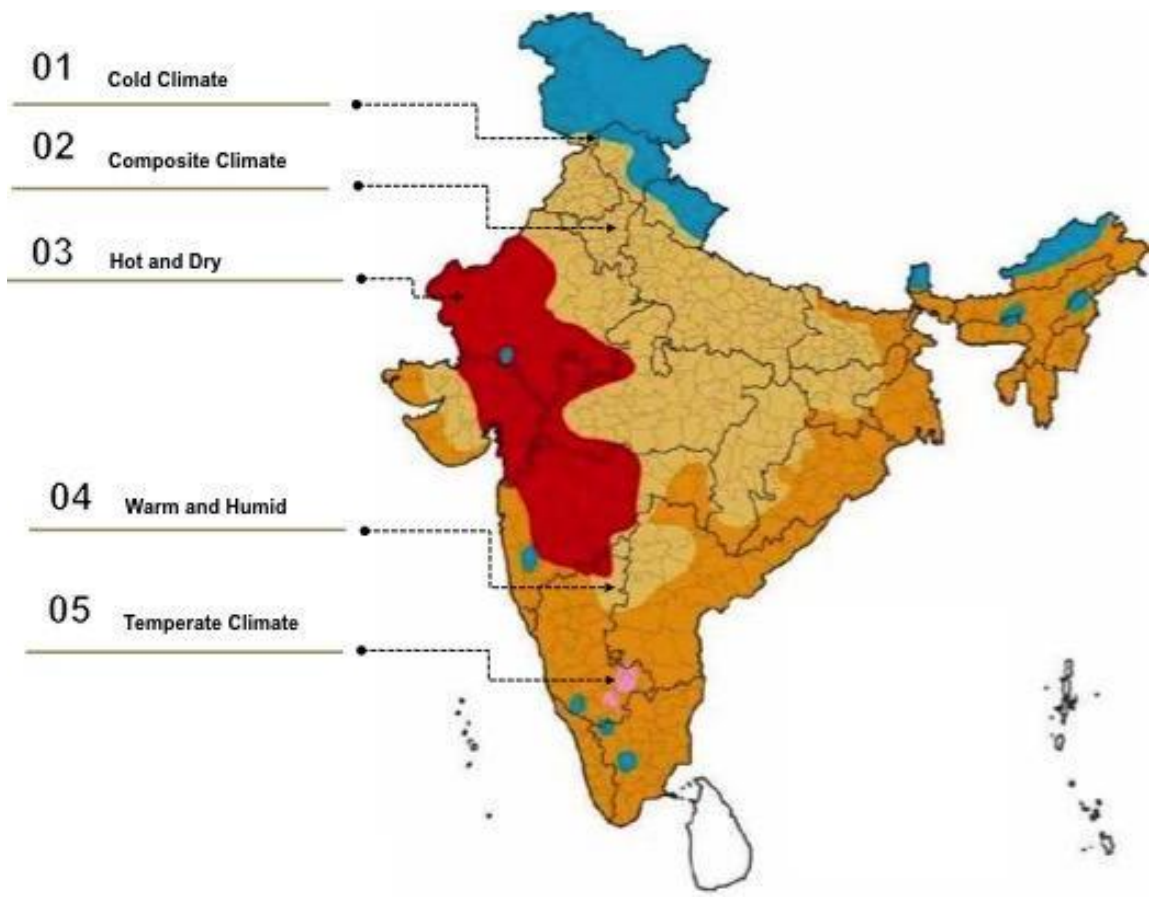

Fig. 1: Map of India indicating the 5 climatic zones. Source: ECBC (2007)

\section{Design Process}

The urban areas encompass a network of buildings serving for living and performing activities. Vitruvius states that the primary function of architecture is that it should provide shelter from the dynamic conditions of the environment. An architect designs buildings and cities considering a complex of laws, rules, sciences including servicing and services, the environment, and the context of the people and society.
An architect/ designer plans a building keeping in mind certain aspects as indicated in Fig. 2. Considerations include, first, the design program including the local bylaws, local context, and surroundings followed by the provisions of urban planning of the respective city. Second, designing an appropriate building form that is often creative in approach while considering certain local conditions. Third, the building facade design is to be functional in terms of addressing the climatic conditions of temperature, humidity,

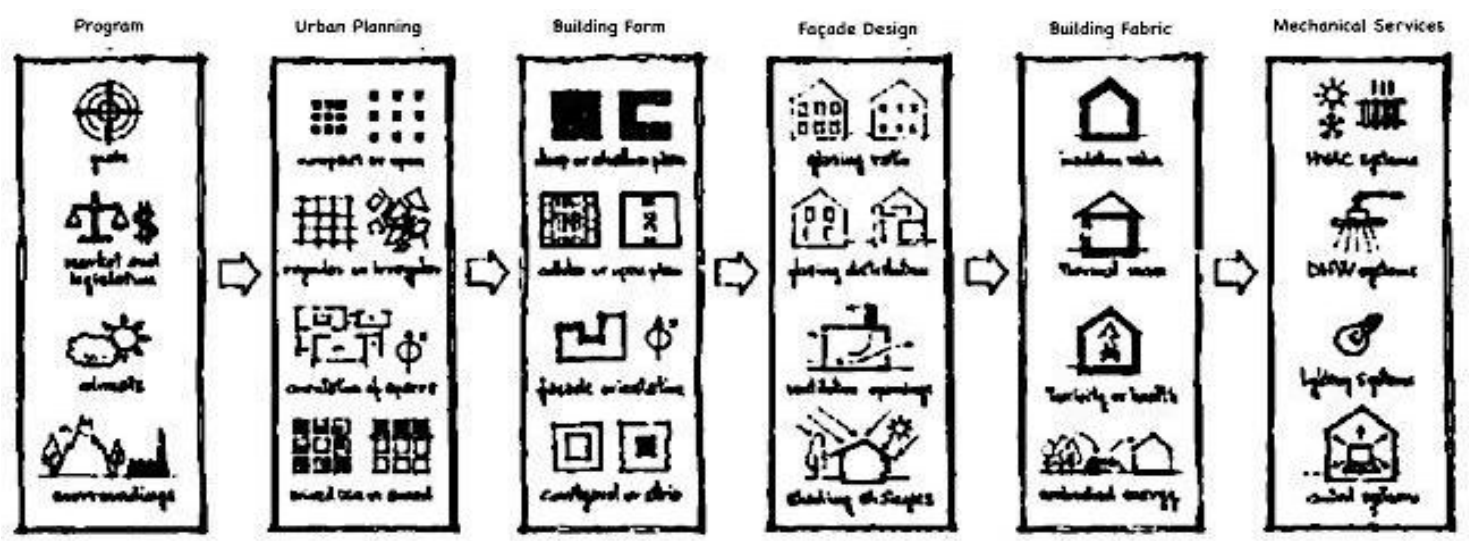

Fig. 2: Phases of design process influencing buildings energy performance and comfort. Source: Aste et al. (2014) 
wind movement, etc. as well as the aesthetic appearance of the building. The building fabric is evolved based on the desired effect of temperature as well as the availability of natural resources. This is then followed by working out of the various services crucial for achieving thermal comfort as well as essential servicing of the building system for effective functioning of the building. Much of the building details are finalized even before the building is built on the site.

Once the building is designed, the only option to ensure thermal comfort would then by using active forms and at the expense of energy consumption. The design process is a major factor in influencing the building's energy performance and comfort as well as energy consumption that directly influence the life costs of the buildings as well as the running costs.

\section{Thermal Comfort}

The fundamental aspect of the environmental quality of the indoor spaces of buildings that are directly related to the satisfaction of occupants and energy use is thermal comfort (Schiavon et al. 2014). Many books used by architects and designers use the 'bioclimatic chart'. Victor Olgyay was the pioneer of thermal comfort who considered Effective Temperature (ET) as the basis for the comfort diagram known as the 'Bioclimatic Chart'. He identified the space within the perimeter of the comfort zone outlined as comfortable to the occupants (Olgyay 1963). The chart also depicted the various ways of extending the comfort zone through increasing radiation, wind speed, and humidity. Givoni (1992, 1998) further depicted the comfort zone in the psychrometric chart with strategies for heating and cooling as depicted in Fig. 3.
The strategies that the thermal comfort area reports through the Bioclimatic Chart have been inconsistent with ASHRAE 55 thermal comfort areas (Schiavon et al. 2014). There are also inconsistencies that have been identified between the initial climate-based files and the later simulations due to the influence of construction, building program, and also the preferences of occupants (Arsano \& Reinhart 2017). Extended boundaries of comfort zones can be formed when wind speeds are taken into account as they have the potential to offset temperatures and are dependent on climate-specific adaptations and comfort expectations (Kumar et al. 2016). Thus, the microclimate of the area where the building is designed also influences thermal comfort. Furthermore, the current comfort standards do not take into account that the thermal comfort requirements also vary in the different climatic zones. The range of solutions to provide thermally comfortable indoors varies from place to place and the right techniques need to be carefully chosen so that there is less reliance on energy consumption.

\section{Parameters for Climate Responsive Building Design}

Architect and environmentalist Arvind Krishan defines that the idea of climatically responsive design is to moderate the conditions around and inside such that they are always within or as close as possible to the comfort zone. The prevalent climatic conditions are generally harsh for most parts of the year and hence the importance of the building design in moderating the indoor conditions to suit the occupants. The difference in the natural climatic conditions to a thermally comfortable built space can be mitigated through a climate-responsive building design (Fig. 4) by incorporating appropriate site planning, building form, envelope materials, opening, daylighting, etc., and without the reliance on active measures.

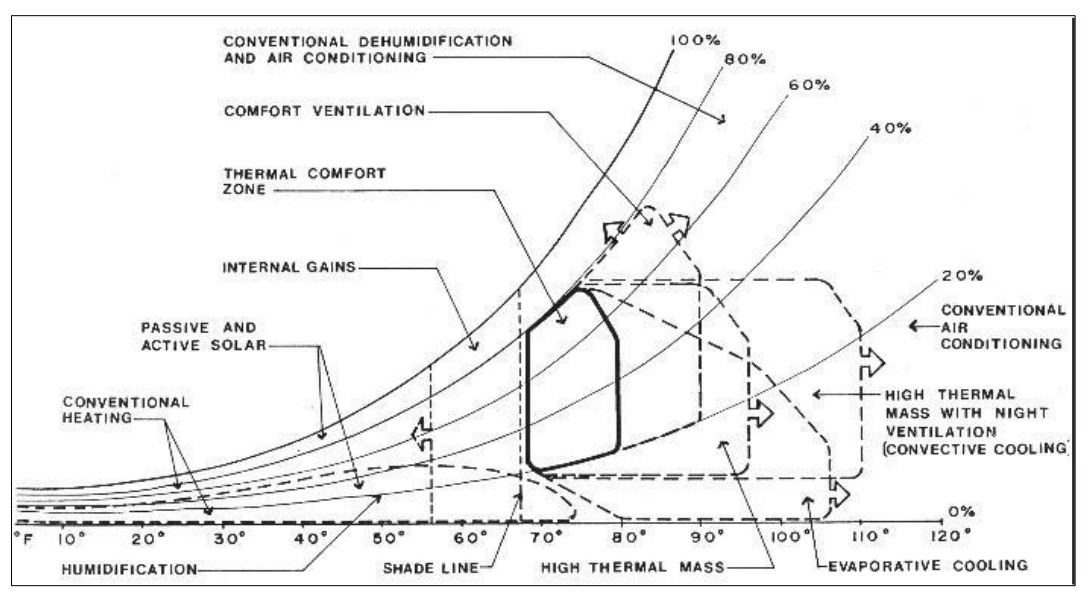

Fig. 3: Summary of design strategies as a function of ambient conditions of climate. Source: Psychrometric-Bioclimatic Chart by Baruch Givoni \& Murray Milne 
Design is initiated by considering the context as the most important parameter and in which the geographical location, as well as the local climate, is of utmost importance. The identification, understanding, and control of the climatic effects at the location of the building are crucial. Arvind Krishan has stratified the design process into 20 aspects (Table 1) of the building and the built environment in a sequence from macro-level details to micro-level aspects in the process of climate-responsive building design wherein climate as a parameter is considered at each level at each aspect. Though all of these aspects are addressed, at some point in any typical design process, the design approach is never a step by step, material by material, or aspect-wise approach. The approach to design is comprehensive and holistic with several aspects addressed together. The recommendations provided are also generic and not specific to the climatic zones in India.

\section{Climate Responsive Strategies by GRIHA and TERI}

Green Rating for Integrated Habitat Assessment (GRIHA) is an Indian rating system, based on accepted energy and environmental principles, that has been instrumental in raising awareness about green design. It assesses the performance of building against nationally acceptable benchmarks. It evaluates the environmental performance of a building holistically over its entire life cycle. It also promotes climate-responsive building design measures, including progressive use of renewable energy. The GRIHA initiative is being followed by various development agencies throughout the country now and is picking up amongst Architects, Engineers, and Construction companies and is now mandated for public buildings. However, the use of the same is also limited and more as guidelines and in terms of suggestions for the climate-based design of buildings.

GRIHA was developed by the Energy and Resources Institute (TERI), a policy research organization working in the fields of energy, environment, and sustainable development. GRIHA addresses the common design elements that directly or indirectly affect the thermal comfort conditions and thereby the energy consumption in a building. It provides recommendations more like generalized suggestions rather than specific inputs for different climatic zones. The inputs from these have also been incorporated into the final climate-based strategy matrix.

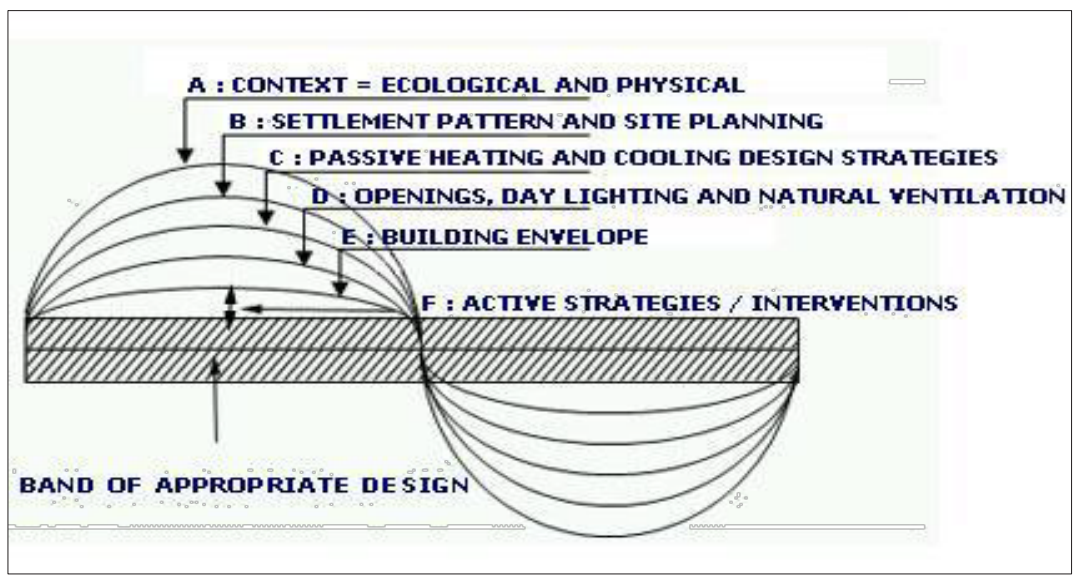

Fig. 4: Addressing conditions to achieve thermally comfortable buildings. Source: Krishnan et al. (2014)

Table 1: The 20 Aspects of the design process for climate-responsive building design.

\begin{tabular}{lll|l|}
$\begin{array}{l}\text { 1. Landform: topography and slope } \\
\text { orientation }\end{array}$ & 7. Plan Form & $\begin{array}{l}\text { 12. Fenestration pattern and } \\
\text { Configuration }\end{array}$ & 18. Internal layout and partitions \\
$\begin{array}{l}\text { 2.Vegetation type and pattern } \\
\text { 3. Water bodies }\end{array}$ & 8. Plan Elements & 13.Fenestration orientation & 19. Internal materials \\
$\begin{array}{l}\text { 4. Street widths and orientation } \\
\text { 9. Bpen spaces and built spaces }\end{array}$ & 10. Surface area to volume ratio & 14. Fenestration Controls & 15. External Colours and textures \\
6. Ground Character & 11. Roof Forms & 16. Roof materials & \\
17. Walls & & \\
\end{tabular}

Source: Krishan et al. (2014) 


\section{DEVELOPING THE CLIMATE RESPONSIVE STRATEGY MATRIX}

Today's buildings in developed countries including India consume a significant portion of the total primary energy. In many of these buildings, adopting energy efficiency strategies, which can be readily adopted by architects and designers, can significantly reduce energy consumption.

\section{Strategies for Climatic Zones by Climate Consultant}

The data available on Psychrometric charts for specific cities that can be viewed on the climate consultant software used for analyzing the prevailing climatic conditions have been extracted as indicated in Table 2 for each of the climatic zones in India.

\section{Grouping of Climate Based Building Design Parameters}

From Arvind Krishan's climate-based building design aspects, 18 aspects have been logically listed down into four groups (Fig. 5) of pre-requisites in line with the normal design process as indicated in Fig. 1 for the purpose of designing a climate-responsive building through a comprehensive, grouped approach. The aspects range from the microenvironment surrounding the site to the finishes of the structure.

These individual groups are further discussed below with strategies for all 5 Indian climatic conditions considering inputs of the climate consultant software, and recommendations of TERI \& GRIHA through a descriptive analysis to present the matrix with strategies. The matrix has further been validated by sample architectural experts from cities cited in Table 3.

\section{CLIMATE RESPONSIVE STRATEGY MATRIX}

The groups described above have been listed below with the suggestions for the corresponding climatic zones. The process follows a four-fold methodology as indicated in Fig. 6.

Table 2: Indicative strategies extracted from Climate Consultant 6.0 for the 5 climatic regions of India.

\begin{tabular}{|c|c|c|}
\hline Climatic Zone & Representative City & Conditions \& Indicative Design Strategy \\
\hline Cold Climate & Shillong & $\begin{array}{l}11 \% \text { is the comfort conditions without reliance on any mechanical means, while through } \\
\text { incorporation of passive means it can be made } 70 \% \text { comfortable through out the year. }\end{array}$ \\
\hline Composite Climate & Delhi & $\begin{array}{l}\text { Through passive techniques, indoor temperature can be made } 52 \% \text { for human comfort condition } \\
\text { while the prevalent climatic conditions indicate only } 14 \% \text { comfort }\end{array}$ \\
\hline Hot and Dry Climate & Ahmedabad & $\begin{array}{l}17 \% \text { in the human comfort zone, building design required to moderate natural conditions to } \\
\text { make indoors comfortable without mechanical support. High heat, strong solar radiations and } \\
\text { low water content in the air to be dealt in design }\end{array}$ \\
\hline Warm and Humid Climate & Chennai & $\begin{array}{l}2.2 \% \text { of prevalent conditions lie in human comfort zone and majority of the time the design } \\
\text { needs to create an comfortable ambient atmosphere to reduce moderate high humidity, high } \\
\text { temperature. }\end{array}$ \\
\hline Temperate Climate & Bengaluru & $\begin{array}{l}26 \% \text { the natural environment is in the human comfort level and through passive means } 94 \% \\
\text { can be made brought to comfort level through out the year. }\end{array}$ \\
\hline
\end{tabular}

Source: Compiled by the authors by accessing Climate Consultant 6.0 on April 25, 2020

Table 3: Cities representative of the 5 climatic zones in India.

\begin{tabular}{|ll|}
\hline Climatic Zone & Representative City \\
\hline Cold Climate & Nainital, Shillong \\
Composite Climate & Delhi, Bhopal \\
Hot and Dry Climate & Ahmedabad, Jaipur \\
Warm and Humid Climate & Chennai, Panjim (Goa) \\
Temperate Climate & Bengaluru, Pune \\
\hline
\end{tabular}

Source: Cities identified by authors for validation of climate responsive strategy matrix 


\section{Site Micro Climate}

Siting a building is a critical exercise as microclimate at times may vary even within the site boundaries at a short distance. Table 4 details the strategy matrix based on aspects related to the site micro and suggests strategies for all 5 zones of Indian climate conditions. For the hot and dry region, where the topography is generally flat, buildings should be located in the valleys and depressions, if such a situation is encountered on site, as these would have a slight dip in the temperature due to the higher density of cool air. Vegetation varies across all climatic zones and hence it is important to utilize its existence to benefit the built environment at large. For instance, in a hot and humid climate, vegetation can be utilized to channelize the naturally occurring high wind velocity to enhance the wind flow towards desired parts of the buildings or they can be utilized as barriers to harsh regional winds in a hot and dry or a harsh cold climate. Similarly, the existence of moisture in the air can produce varying results depending upon the external temperature conditions as moist air can hold more heat than dry air. In hot and dry weather with moderate wind velocity, the introduction of more moisture

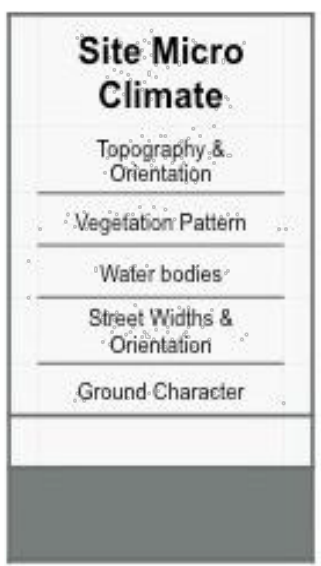

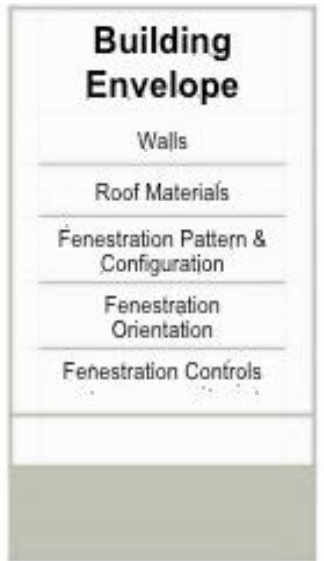

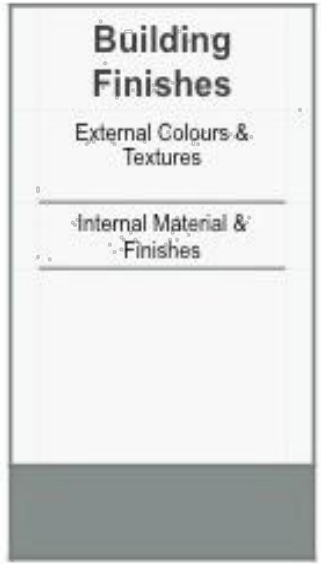

Fig. 5: Groups of parameters for climate-responsive building design. Source: Adapted by authors from Arvind Krishnan's 20 design aspects

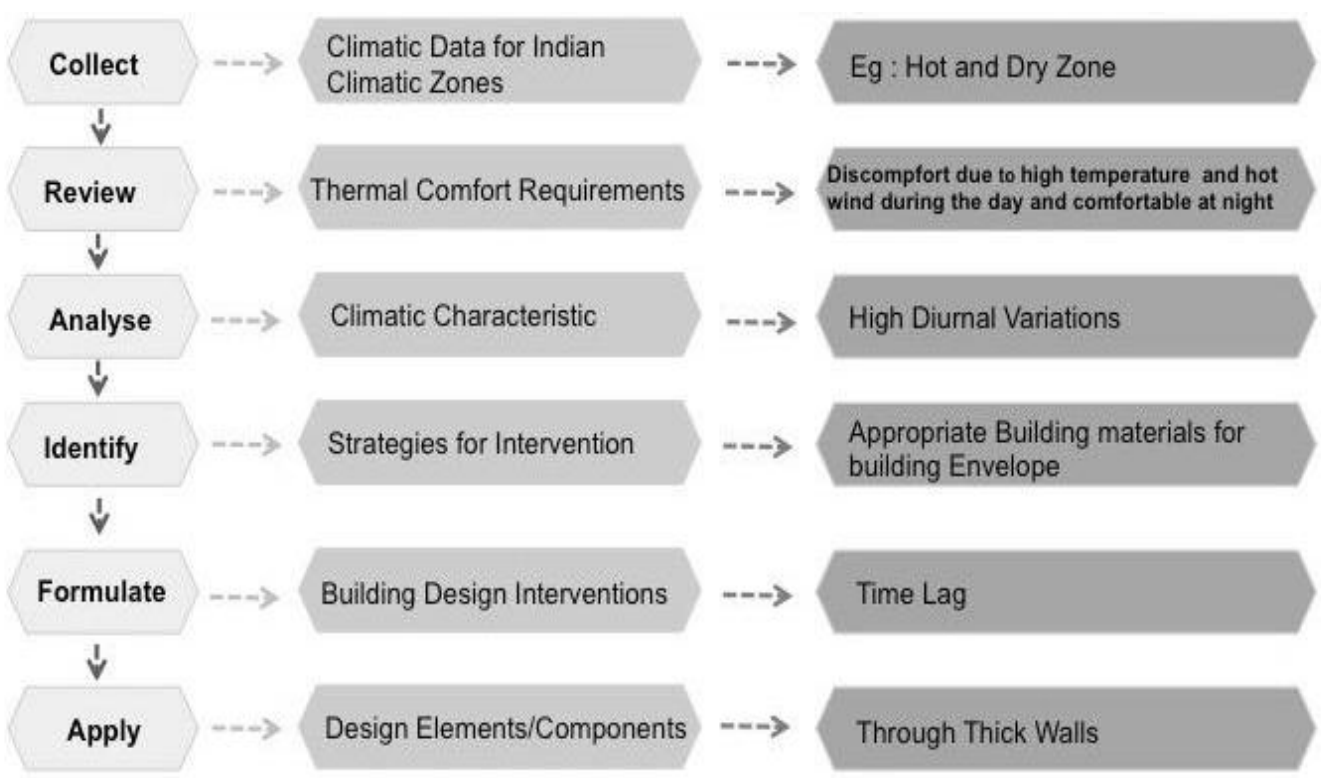

Fig. 6: Methodology followed for developing recommendations.

Source: Authors 
Table 4: Strategies to address site microclimate in all the 5 climatic zones.

\begin{tabular}{|c|c|c|c|c|c|}
\hline & Cold & Composite & Hot and Dry & Warm \& Humid & Temperate \\
\hline $\begin{array}{l}\text { Landform : } \\
\text { Topography } \\
\text { Orientation }\end{array}$ & $\begin{array}{l}\text { Generally high alti- } \\
\text { tudes / hills. South-fac- } \\
\text { ing slopes preferred. }\end{array}$ & $\begin{array}{l}\text { Plains \& Plateaus. } \\
\text { Higher levels are } \\
\text { preferred }\end{array}$ & $\begin{array}{l}\text { Generally Flat. De- } \\
\text { pressions and valleys } \\
\text { preferred }\end{array}$ & $\begin{array}{l}\text { Generally sloping towards } \\
\text { the coast. North slopes in } \\
\text { shade and slopes facing wind } \\
\text { direction are preferred. }\end{array}$ & High Plateaus \\
\hline $\begin{array}{l}\text { Vegetation } \\
\text { Pattern }\end{array}$ & $\begin{array}{l}\text { a) Dense Forest. Ev- } \\
\text { ergreen trees cut cold } \\
\text { winds but shade may } \\
\text { block sun. } \\
\text { b) Cold Desert. Scanty } \\
\text { vegetation. }\end{array}$ & $\begin{array}{l}\text { Seasonal. Deciduous } \\
\text { vegetation to control } \\
\text { sun. }\end{array}$ & $\begin{array}{l}\text { Usually Scanty \& dry } \\
\text { surrounding. Trees } \\
\text { planted to cut off east- } \\
\text { west sun. }\end{array}$ & $\begin{array}{l}\text { Dense vegetation, Tree } \\
\text { should channel the wind and } \\
\text { maximize airflow. }\end{array}$ & $\begin{array}{l}\text { Well Vege- } \\
\text { tated. Trees } \\
\text { planted to } \\
\text { shade. }\end{array}$ \\
\hline Water Bodies & $\begin{array}{l}\text { When enclosed can } \\
\text { store heat and control } \\
\text { heat loss. For Cold Dry } \\
\text { add humidity to air }\end{array}$ & $\begin{array}{l}\text { Preferred during } \\
\text { summers but should be } \\
\text { drained during mon- } \\
\text { soons and winters }\end{array}$ & $\begin{array}{l}\text { Enables evaporative } \\
\text { cooling and directs } \\
\text { cool breeze indoors. }\end{array}$ & $\begin{array}{l}\text { Not recommended as it adds } \\
\text { to humidity levels. }\end{array}$ & $\begin{array}{l}\text { Enable cool- } \\
\text { ing and direct } \\
\text { cool breeze } \\
\text { indoors. }\end{array}$ \\
\hline $\begin{array}{l}\text { Street Widths } \\
\text { \& Orientation }\end{array}$ & $\begin{array}{l}\text { Narrow to prevent cold } \\
\text { drafts (E-W Oriented) }\end{array}$ & $\begin{array}{l}\text { Should be narrow (N-S } \\
\text { Oriented) and oriented } \\
\text { to receive monsoon } \\
\text { winds. }\end{array}$ & $\begin{array}{l}\text { Should be narrow and } \\
\text { shaded (N-S Oriented) }\end{array}$ & $\begin{array}{l}\text { Preferably wide to pro- } \\
\text { mote air movement }\end{array}$ & $\begin{array}{l}\text { Shaded } \\
\text { streets }\end{array}$ \\
\hline $\begin{array}{l}\text { Ground Char- } \\
\text { acter }\end{array}$ & $\begin{array}{l}\text { Paved, dark and } \\
\text { smooth to increase ab- } \\
\text { sorptivity and avoiding } \\
\text { Glare }\end{array}$ & $\begin{array}{l}\text { Green Non-reflective } \\
\text { ground cover }\end{array}$ & $\begin{array}{l}\text { Not reflective, rough } \\
\text { surface for diffusing } \\
\text { radiation, more softs- } \\
\text { cape, light coloured } \\
\text { paving }\end{array}$ & $\begin{array}{l}\text { Not absorptive, } \\
\text { rough, some hardscape and } \\
\text { dry ground around buildings }\end{array}$ & $\begin{array}{l}\text { Balanced } \\
\text { softscape and } \\
\text { hardscape }\end{array}$ \\
\hline
\end{tabular}

Source: Compiled by authors and validated by a survey

can induce a feeling of more comfort, whereas in an already humid condition, more discomfort can be experienced and in a cold climate, water can be used to trap the heat and release it to the interior environment.

Along with moderating the natural conditions to benefit the manmade environment, careful planning of the built environment too can create a positive impact on the thermal comfort conditions inside the built envelope. The orientation and spacing between buildings can be varied to either promote or to cut off the impact of one or more elements of climate. It is favorable in some conditions of the cold climatic zones of the country to increase the absorptivity of solar radiations to release the absorbed heat at lower temperatures at night, but in the case where the atmospheric temperature is already soaring, having reflective or absorptive surfaces can further add on the heat in the environment.

The surrounding environment, as well as the building, can positively or negatively impact each other and therefore careful considerations must be given to locating the building or planned elements on the site as well as surface treatments of the ground around it.

\section{Building Form and Massing}

The next step in the building design process after the contextual analysis is to moderate and orient the built mass with an underlying understanding of the solar geometry, wind directions, precipitation, and other determinants of climate to maximize or minimize the impact of solar radiation, wind movements, and moisture content within the building depending on the climatic data available for that zone. In a hot and dry region, a more compact built form is preferred with contained inward-looking open spaces so that there is a minimum interface with outside temperature hence also having a minimum perimeter to area ratio. It bears similarity to the structure in a cold zone where a similar compact form is desired to contain the heat within the space, but orienting windows towards the south side to trap the south sun. And similarly, the other climate suggestions are provided that may suit the respective climatic zone.

Apart from working out an appropriate form of the structure, planning of some elements like courtyards, atriums, Trombe walls, etc. can help in creating a thermally suitable atmosphere for the inhabitants. In the cold climatic zones like Leh and Ladakh, utilization of the solar radiation is the only source of natural heating of the indoor environment and hence providing sunspaces that are oriented towards the south or providing the traditional technique of Trombe wall that can trap the heat and later release the trapped heat at 
night can be beneficial in a responsive design by relying less on heating through active means. Table 5 below discusses strategies for built form and mass.

\section{Building Envelope}

The building envelope as discussed in Table 6 is the thermal barrier between the external and the internal environment. Each element of the building envelope i.e. floor, walls, roof, fenestration, etc. contributes to heat exchange between the two sides and if appropriately designed by selecting the right materials and construction details, it could minimize the thermal impact (Akeel et al. 2017). Fenestration itself can constitute a large part of undesired heat ingress or egress not appropriately planned for the climatic situation where it has to be located. In designing fenestration, the following factors may be considered for a climate-responsive building design which are the size of the openings, its material selection, and assembly, the orientation, the pattern whether openable or closed, and the shading requirements. Due to the potential heat intake it can have a hot and dry climate, windows should be planned smaller in size and well shaded, located at two levels preferably their orientation towards East and West should be avoided. In warm and humid conditions, where the wind is required in all parts of the buildings, windows are placed keeping in mind cross ventilation, openable yet an assembly that can keep the heat out as much as possible. In the colder zone, windows that allow the south sun during the windows are provided.
Walls and roofs take in a large amount of heat in the typical heat-dominated tropical climate. Selection of material for the roofs and wall is done with an underlying understanding of how a material would behave when subjected to heat on one of the sides and accordingly appropriate construction techniques and wall assemblies are then constituted to create the envelope that would keep the interiors comfortable. Mud or brick walls have a very different thermal property from concrete and glass. Shading devices protecting the external openings and fenestration from the harsh climates enhance the performance of the envelope, particularly in a hot country like ours. The material and construction technique used in the envelope modifies the thermal characteristics of the envelope. While dark heat-insulating material like timber is preferred in cold climates, massive heat-storing materials or cavity walls are preferred in hot dry and lighter masonry structures transparent to wind performs best in humid zones.

\section{Building Finishes}

Surface finishes (see strategies for building Finishes in Table 7) in terms of color and texture also modify the thermal characteristics of a built environment. External and internal surface finishes, colors, and textures impact the heat transfer into the structure due to their various properties such as density, specific heat capacity, emissivity, color, albedo, absorptivity, transmittance, and roughness (Hwaish, 2018). One or a combination of the above factors can increase or decrease the amount of thermal transfer through conduction, convection,

Table 5: Strategies to address building form and massing in all the 5 climatic zones.

\begin{tabular}{|c|c|c|c|c|c|}
\hline & Hot \& Dry & Warm \& Humid & Composite & Cold & Temperate \\
\hline $\begin{array}{l}\text { Built Form \& } \\
\text { Open Spaces }\end{array}$ & $\begin{array}{l}\text { Compact for mutual } \\
\text { shading with small open } \\
\text { spaces }\end{array}$ & $\begin{array}{l}\text { Open Planning to pro- } \\
\text { mote air circulation }\end{array}$ & $\begin{array}{l}\text { Compact planning, low rise } \\
\text { development }\end{array}$ & $\begin{array}{l}\text { Open spaces to be } \\
\text { small but allow } \\
\text { south sun. }\end{array}$ & $\begin{array}{l}\text { Open Planning for } \\
\text { thermal comfort }\end{array}$ \\
\hline Plan Form & $\begin{array}{l}\text { Minimum Perimeter to } \\
\text { Area ratio, Shaded and } \\
\text { semi covered areas as } \\
\text { buffers }\end{array}$ & $\begin{array}{l}\text { Minimum Perimeter to } \\
\text { Area ratio but shaped and } \\
\text { supporting maximum air } \\
\text { movement. }\end{array}$ & $\begin{array}{l}\text { Minimum Perimeter to Area } \\
\text { ratio. Mutual shading. Open } \\
\text { to monsoon winds. }\end{array}$ & $\begin{array}{l}\text { Minimum Perime- } \\
\text { ter to Area ratio for } \\
\text { reduce heat loss. }\end{array}$ & $\begin{array}{l}\text { Minimum Perim- } \\
\text { eter to Area ratio } \\
\text { for minimum heat } \\
\text { gain. }\end{array}$ \\
\hline $\begin{array}{l}\text { Plan Elements } \\
\text { Integrated }\end{array}$ & $\begin{array}{l}\text { Shaded Courtyards, } \\
\text { Fountains, water chan- } \\
\text { nels, wind towers/catch- } \\
\text { ers, earth air tunnel, } \\
\text { Terrace/Roof gardens, } \\
\text { window planters }\end{array}$ & $\begin{array}{l}\text { Open courtyards/atrium, } \\
\text { balconies, patios, ve- } \\
\text { randahs. Wind Tunnels, } \\
\text { Windcatchers to catch } \\
\text { breeze. }\end{array}$ & $\begin{array}{l}\text { Shaded Courtyards, Foun- } \\
\text { tains, hybrid structures (sepa- } \\
\text { rate summer/monsoon areas), } \\
\text { earth air tunnel, pergola with } \\
\text { creepers }\end{array}$ & $\begin{array}{l}\text { Sun spaces, Green- } \\
\text { house, trombe } \\
\text { wall, light wells, } \\
\text { light shelves, ther- } \\
\text { mal chimney, wa- } \\
\text { ter walls }\end{array}$ & $\begin{array}{l}\text { Shaded courtyards, } \\
\text { Shading devices } \\
\text { for fenestration, } \\
\text { balconies, Roof } \\
\text { gardens }\end{array}$ \\
\hline $\begin{array}{l}\text { Building Ori- } \\
\text { entation }\end{array}$ & $\begin{array}{l}\text { Longer facades facing } \\
\text { North South, primarily to } \\
\text { minimize heat gain }\end{array}$ & $\begin{array}{l}\text { Longer facades North } \\
\text { South or more preferably } \\
\text { oriented as per the wind } \\
\text { direction }\end{array}$ & $\begin{array}{l}\text { Longer facades facing North } \\
\text { South, primarily to minimize } \\
\text { heat gain and to catch mon- } \\
\text { soon winds }\end{array}$ & $\begin{array}{l}\text { Oriented for maxi- } \\
\text { mum sun, prefera- } \\
\text { bly South }\end{array}$ & $\begin{array}{l}\text { Longer facades } \\
\text { facing North } \\
\text { South, primarily to } \\
\text { minimize heat gain }\end{array}$ \\
\hline S/V Ratio & minimum $\mathrm{S} / \mathrm{V}$ ratio & $\begin{array}{l}\mathrm{S} / \mathrm{V} \text { ratio to create shaded } \\
\text { airy spaces }\end{array}$ & minimum $\mathrm{S} / \mathrm{V}$ ratio & minimum $\mathrm{S} / \mathrm{V}$ ratio & minimum $\mathrm{S} / \mathrm{V}$ ratio \\
\hline $\begin{array}{l}\text { Roof Form \& } \\
\text { Overhangs }\end{array}$ & $\begin{array}{l}\text { Flat or Shaded roofs to } \\
\text { minimize heat gain }\end{array}$ & $\begin{array}{l}\text { Pitched roofs with large } \\
\text { overhangs }\end{array}$ & $\begin{array}{l}\text { Large eaves to shade walls } \\
\text { and openings }\end{array}$ & $\begin{array}{l}\text { Flat roofs to mini- } \\
\text { mize heat loss }\end{array}$ & $\begin{array}{l}\text { Light roofs with } \\
\text { deep overhangs }\end{array}$ \\
\hline
\end{tabular}


Table 6: Strategies to address building envelope in all the 5 climatic zones.

\begin{tabular}{|c|c|c|c|c|c|}
\hline & Hot \& Dry & Warm \& Humid & Composite & Cold & Temperate \\
\hline $\begin{array}{l}\text { Fenestration Pat- } \\
\text { tern \& Configu- } \\
\text { ration }\end{array}$ & $\begin{array}{l}\text { Small Openings to pre- } \\
\text { vent wind carrying sand, } \\
\text { shaded to cool hot breeze. } \\
\text { High level heat vents }\end{array}$ & $\begin{array}{l}\text { Large and body } \\
\text { level well-shaded } \\
\text { fenestration. Cross } \\
\text { ventilation arrange- } \\
\text { ment }\end{array}$ & $\begin{array}{l}\text { Two level small open- } \\
\text { ings. Operable and shaded. } \\
\text { Maximum on monsoon } \\
\text { windward side. }\end{array}$ & $\begin{array}{l}\text { Large glazed areas, } \\
\text { unshaded but well } \\
\text { sealed. }\end{array}$ & $\begin{array}{l}\text { Large well shaded } \\
\text { and sealed fenestra- } \\
\text { tion }\end{array}$ \\
\hline $\begin{array}{l}\text { Fenestration ori- } \\
\text { entation }\end{array}$ & $\begin{array}{l}\text { North facing primarily, } \\
\text { also sunny spaces for win- } \\
\text { ter sun }\end{array}$ & $\begin{array}{l}\text { Staggered and in the } \\
\text { direction of airflow }\end{array}$ & $\begin{array}{l}\text { Towards south for cold } \\
\text { season and towards mon- } \\
\text { soon winds }\end{array}$ & South facing & North facing \\
\hline $\begin{array}{l}\text { Fenestration } \\
\text { Controls }\end{array}$ & $\begin{array}{l}\text { Shaded Fenestration, Low } \\
\text { E Value Glass, Louvers, } \\
\text { sun breaks }\end{array}$ & $\begin{array}{l}\text { Solar radiation is } \\
\text { diffuse. So shading } \\
\text { not important. Fly- } \\
\text { wire net to ward off } \\
\text { insects }\end{array}$ & $\begin{array}{l}\text { Shaded openable Fenes- } \\
\text { tration, Low E Value } \\
\text { Glass, Louvers, sun breaks }\end{array}$ & $\begin{array}{l}\text { Optimum glazing, } \\
\text { well-sealed, un- } \\
\text { shaded }\end{array}$ & openable windows \\
\hline Walls & $\begin{array}{l}\text { Adobe construction, ma- } \\
\text { sonry with high thermal } \\
\text { mass, low U, reflective } \\
\text { insulation, green walls, } \\
\text { AAC blocks, hollow } \\
\text { blocks, composite ma- } \\
\text { sonry, stone/ tile cladding }\end{array}$ & $\begin{array}{l}\text { Low U walls. Low } \\
\text { thermal mass. Insu- } \\
\text { lation are effective }\end{array}$ & $\begin{array}{l}\text { Masssive walls at lower } \\
\text { levels. Light structures at } \\
\text { upper levels. }\end{array}$ & $\begin{array}{l}\text { Wall to have low } \\
\text { U value. Thermal } \\
\text { mass for heat stor- } \\
\text { age. Trombe walls, } \\
\text { Trombe wall with } \\
\text { vents, Solar wall, } \\
\text { Water wall }\end{array}$ & $\begin{array}{l}\text { Walls with low U fac- } \\
\text { tor for minimum heat } \\
\text { loss. Trombe walls, } \\
\text { Trombe wall with } \\
\text { vents, Solar wall, } \\
\text { Water wall }\end{array}$ \\
\hline Roof Materials & $\begin{array}{l}\text { Adobe construction, roof } \\
\text { with high thermal mass, } \\
\text { reflective insulation, green } \\
\text { roofs, earthen pots, roof- } \\
\text { ing tiles }\end{array}$ & $\begin{array}{l}\text { Roof to have low } \\
\text { U value and have } \\
\text { low heat capacities } \\
\text { (light roofs). }\end{array}$ & $\begin{array}{l}\text { Light roofs, well insulated, } \\
\text { low U values }\end{array}$ & $\begin{array}{l}\text { Low } U \text { value roofs, } \\
\text { adobe, stone roof } \\
\text { with high thermal } \\
\text { mass }\end{array}$ & $\begin{array}{l}\text { Roofs with low } U \\
\text { value and roofing tiles }\end{array}$ \\
\hline
\end{tabular}

Table 7: Strategies to address building finishes in all 5 climatic zones.

\begin{tabular}{|llllll|}
\hline & Hot \& Dry & Warm \& Humid & Composite & Cold & Temperate \\
\hline $\begin{array}{l}\text { External Colors } \\
\text { \& Textures }\end{array}$ & $\begin{array}{l}\text { Light Colours, tex- } \\
\text { tured walls for shading }\end{array}$ & $\begin{array}{l}\text { Light Colours, rough } \\
\text { textured walls }\end{array}$ & $\begin{array}{l}\text { Light Coloured exteriors } \\
\text { (white wash in summer) }\end{array}$ & $\begin{array}{l}\text { Dark Colours \& flat } \\
\text { surfaces }\end{array}$ & $\begin{array}{l}\text { Light / Dark, Smooth/ } \\
\text { Rough textures }\end{array}$ \\
$\begin{array}{l}\text { Internal Mate- } \\
\text { rials \& Finishes }\end{array}$ & $\begin{array}{l}\text { Light furniture and in- } \\
\text { teriors to reduce heat } \\
\text { absorption, matt fin- } \\
\text { ishes }\end{array}$ & $\begin{array}{l}\text { Light furniture and } \\
\text { interiors to reduce heat } \\
\text { absorption and im- } \\
\text { prove lighting levels }\end{array}$ & $\begin{array}{l}\text { Light Colours and tex- } \\
\text { tures to reduce heat ab- } \\
\text { sorption }\end{array}$ & $\begin{array}{l}\text { Dark Colours and } \\
\text { heavy furniture to } \\
\text { promote heat absorp- } \\
\text { tion }\end{array}$ & Light/Dark \\
\hline
\end{tabular}

or radiation. Smooth light-colored plasters radiate much of the incoming radiation while textured coatings absorb and add heat into the building. Within the buildings, the color of walls, ceilings, and furniture also reflects or absorbs incoming radiations and modifies the thermal properties of the inside space. It is a known fact that darker colors absorb more heat than lighter shades. Hence warmer the climate, lighter shades are preferred and colder the climate the dark colors help to absorb or retain the heat within the interior atmosphere.

\section{CONCLUSIONS}

The building industry is a large contributor to the rising environmental degradation and every year the energy consumption in buildings is increasing alarmingly. The major reason being the utilization of active energy-consuming appliances for the creation of desired comfort conditions within the building. The architects and designers, who have a major role in the building design process, need to acknowledge the need for designing naturally for thermal comfort thereby reducing the pressure on artificial conditioning of indoor environs.

The paper provides a very simplified way of the entire design process that should be carried out to create a thermally responsible structure, which not only provides comfortable indoor spaces to the inhabitants but also reduces the need for energy-consuming cooling/heating appliances/systems and its negative impacts on the environment at large. The paper provides an easy to comprehend concise matrix that should be considered to create suitable massing and choosing the 
building component and materials for each climate condition that also is essential for sustainable development. Not every building has the same weather exposure. Regional climate conditions, macro environment, and site microclimate all affect the built-up indoor environment and must be taken into account in the design process of a climate-responsive building.

\section{REFERENCES}

Akeel, H., Al-Mulla, N. and Almulla, H. 2017. Impacts of heat exchange on building envelope in hot climates. J. Int. J. Emerg. Technol. Adv. Eng., 5 (2): 47-57.

Albatayneh, A., Alterman, D., Page, A. and Moghtaderi, B. 2018. The significance of building design for the climate. J. Environ. Clim. Technol., 22: 165-178.

Arsano, Y A. and Reinhart, C. 2017. A comparison of methods for evaluating ventilation cooling potential building program-based climate analysis for early design decisions. In: $15^{\text {th }}$ International Conference. Proceedings of International Building Performance Simulation Association (IBPSA), San Francisco, USA.

Aste, N., Butera, F. and Adhikari, R. 2014. Sustainable Building Design for Tropical Climates: Principles and Applications for Eastern Africa. UN-Habitat, Nairobi, Kenya

Choi, J., Shin, J., Kim, M. and Kim, I. 2016. Development of open BIMbased energy analysis software to improve the interoperability of energy performance assessment. J. Auto. Const., 72: 52-64.

Givoni, B. 1998. Climate Considerations in Buildings and Urban Design. Wiley \& Sons, New Jersey, USA, pp.185.

Givoni, B. 1992. Comfort, climate analysis, and building design guidelines. Energy and Buildings, 18:11-23.
Hwaish, A. N. A. 2018. Sustainable design for building envelope in hot climate; a case study for the role of the dome as a component of the roof in heat exchange. International Journal of Advanced Engineering, Management and Science, 4(2): 126-134.

Harish, V.S. and Kumar, A. 2016. A review on modeling and simulation of building energy systems. J. Renew. Sust. Energy Rev., 56: 72-92.

Jung, D.K., Lee, D.H., Shin, J.H., Song, B.H. and Park, S.H. 2013. Optimization of energy consumption using BIM-based building energy performance analysis. J. Appl. Mech. Materials, 281: 649-652.

Kovacic, I. and Zoller, V. 2015. Building life cycle optimization tools for early design phases. Energy, 92: 409-419.

Krishnan, A., Baker, N., Yannas, S. and Szokolay, S. 2014. Climate Responsive Architecture: A Design Handbook for Energy Efficient Buildings. Tata McGraw-Hill Education, New York.

Kumar, S., Mathur, J., Mathur, S., Singh, M. K. and Loftness, V. 2016. An adaptive approach to define thermal comfort zones on psychrometric chart for naturally ventilated buildings in the composite climate of India. J. Build. Environ., 109: 135-153.

Olgyay, V. 1963. Design with Climate: A Bioclimatic Approach to Architectural Regionalism. Princeton University Press, New Jersey, USA.

Perez-Lombard, L., Ortiz, J. and Pout, C. 2008. A review on buildings energy consumption information. Energy Build., 40(3): 394-398.

Schiavon, S., Hoyt, T. and Piccioli, A. 2014. Web application for thermal comfort visualization and calculation according to ASHRAE standard 55. J. Build. Simul., 7(4): 321-334.

Venkataraman, A. and Kannan, R. 2013. Whole Building Energy Analysis using BIM. In: $4^{\text {th }}$ International Conference Proceedings of International Conference on Advances in Civil Engineering AETACE, NCR, India, pp. 935-943.

Yilmaz, Z. 2007. Evaluation of energy-efficient design strategies for different climatic zones: Comparison of thermal performance of buildings in temperate-humid and hot-dry climate. J. Energ. Build., 39: 306-316. 